\title{
Content Analysis of Recordkeeping Job Advertisements in Western Australia: Knowledge and Skills Required by Employers
}

\author{
MARGARET PEMBER
}

ABSTRACT Since professional education for recordkeeping first commenced the nature of the profession has changed considerably and courses have undergone a number of metamorphoses. One of the major drivers for course change should be industry need. A content analysis of a sample of Western Australian recordkeeping job advertisements was conducted to identify the specific knowledge and skills in demand by employers.

From an analysis of the positions advertised it is clear that employers expect recordkeeping professionals to possess a diverse range of recordkeeping knowledge and experience, ranging from basic entry-level hands-on processing skills to high level strategic planning skills. Often positions require knowledge and experience in more than one area of information management, for example, recordkeeping and librarianship or recordkeeping and freedom of information. The preferred recordkeeping professional will also be proficient in transferable employment competencies such as a high level of computer literacy, well developed communication and interpersonal skills, staff management skills and experience, well developed teaming skills, and a strong customer focus. Personal attributes such as enthusiasm, motivation, and analytical and problem solving skills were also considered of great importance.

Over one-third of the advertisements indicated that a tertiary qualification or progress towards a tertiary qualification was required as either an essential or a desirable criterion, but only $10 \%$ mentioned membership of a relevant professional association.

$\mathrm{T}$

2002 NSW records compliance audit conducted by the NSW Audit Office $^{1}$ showed that the majority of agencies was not totally compliant with the standards audited. ${ }^{2}$ Only 12 agencies were totally compliant and this in a state with a relatively long history of strong and active leadership in public records management. Evans ${ }^{3}$ assessment of the audit report identifies a serious professional skills weakness among recordkeeping staff in the New South Wales public sector. Furthermore, Evans argues 'that without a skilled and professionally qualified workforce as required in the standards Principle 7 [Standard on Records Management Programs ${ }^{4}$ ], there is little chance of total compliance with the principles audited or any other standards'. Many records staff members simply do not have the knowledge and skills necessary for the required level of recordkeeping implementation and practice. As Evans suggests, agencies need an understanding of the skills required for 'best practice' recordkeeping, a regular skills audit of staff, an analysis of skills Margaret Pember, Lecturer, Information Studies, Faculty of Media, Society \& Culture, Curtin University of Technology, GPO Box U1987, Perth WA 6845. Email: m.pember@ curtin.edu.au 
development needs and the necessary resources to enable these needs to be addressed effectively through appropriate staff training and education.

Evans' research, which is supported by anecdotal evidence from employers and the experience of recruitment consultants such as Information Enterprises Australia, ${ }^{5}$ also indicates that there may be a significant divide between industry needs and professional education and even access to the educational opportunities available. Evans' research conducted in late 2001 raises the issue of 'intra-office jealousies' and suggests that 'in some organisations well paid records managers without professional qualifications were preventing staff from undertaking training or discouraging them from obtaining qualifications. The belief was that those who undertook training or acquired qualifications were a threat.' This is significant as Evans' survey of RMAA members in New South Wales ${ }^{6}$ indicated that $61 \%$ did not have any qualification in records management or archives. The major reason given for this lack of qualification (50.5\%) was the belief that the experience they possessed was equal to formal qualifications and entitled them to be considered a professional despite the lack of a recognised qualification.

\section{Appropriate Training and Education}

Evans stresses the need for an appropriately 'skilled and professionally qualified workforce as a key step towards ensuring compliance'. ${ }^{7}$ How this is achieved will continue to be a challenge for regulators and those with responsibility for the records program at the organisational level. State Records New South Wales should be commended for the speed and thoroughness with which they are addressing these concerns in their jurisdiction through the Building Better Records Management Skills guideline. ${ }^{8}$

The recordkeeping discipline has undergone enormous change in the past two decades. This change has necessitated an evolvement of the records practitioner from a relatively unskilled passive receiver of paper-based records (para-professional/filing clerk) to one of highly knowledgeable and skilled proactive professional in the information/knowledge industry with ever increasing expectations from employers and regulators. This will be very difficult for practitioners without a reassessment and deliberate planning of their education and training needs. Cunningham, in his Handbook for Records Management Careers, ${ }^{9}$ notes that in America:

Records managers today are unlike librarians or archivists in that they are; 1 ) better paid and, 2) they tend to move to better jobs more often. In the 1998 Listserv salary survey ${ }^{10}$ the average salary for an archivist was $\$ 35,500$ compared to the average salary for a records manager at $\$ 47,500$ [\$US]. The average archivist in the survey had been in their position six years, compared to the records manager at 4.5 years. There are advantages and disadvantages to these attributes. While often better paid, records managers also have a higher level of responsibility and accountability. 
What are the appropriate knowledge and skills required by records managers today? Perhaps it is the acquisition of the requisite domain specific skills and/or knowledge to perform the required duties of a defined position or role in an agency, the level and type of skills and knowledge varying with the level of the position. First one must determine what these requirements are. Hopefully they are clearly defined in current position descriptions but this is not always the case. ANTA (Australian National Training Authority) defines training as 'the development of skills, knowledge, attitudes, competencies etc through instruction or practice,' and education as '(1) the process of imparting knowledge or developing skills, understanding, attitudes, character or behaviours, (2) the process of acquiring knowledge, skills, understanding, attitudes etc, (3) the knowledge, skills, understanding, attitudes etc acquired, and (4) the field of study concerned with teaching and learning. ${ }^{, 11}$

However defined, it is generally agreed that 'training' is a key element in the acquisition or improvement of hands-on technical skills whereas 'education' relates to the development of an additional broader understanding of the theory and practice of a discipline as well as the ability to think and analyse complex issues. As $\operatorname{Cox}^{12}$ notes, education provides the basis for careers and is not simply the acquisition of skills for short-term technicians' labour. Webster ${ }^{13}$ argues that 'university education provides students with much more than practical "how-to-do-it" knowledge - it is designed to underpin this knowledge with a theoretical basis (why it is done) and provoke critical inquiries into the nature of the discipline.' In many fields this disparity between training and education creates a divide between para-professionals and professionals even if the specific terminology is not encouraged. This is not to say that never the twain shall meet. In the past in Australia, the majority of successful records managers have come up through the ranks or from other information disciplines.

\section{Is Recordkeeping Really a Profession?}

Most definitions of a discipline or profession revolve around the issues of qualifications, a core body of knowledge, and a professional body etc. Liles et $a l^{14}$ isolate six characteristics of a discipline: a focus of study, a world view or paradigm, a set of reference disciplines used to establish the discipline, principles and practices associated with the discipline, an active research or theory development agenda, and relevant education and the promotion of professionalism. Some would say that the recordkeeping profession does not yet meet all these criteria, but it is clear that it has come a long way in the past decade.

Liles, Johnson and Meade ${ }^{15}$ emphasise that 'education and professionalism are essential to the widespread recognition and deployment of 
a discipline'. Both the Records Management Association of Australasia and the Australian Society of Archivists have long been interested in the issues of professionalism and professional education. The degree of interest has waxed and waned over the past decade and is approached differently by the two professional bodies. The current differences between the approaches centre mainly on the requirements for professional recognition. Discussion at the June 2003 ARES (Archives and Records Education Stakeholders) Forum indicates that there will be no easy or quick resolution of these differences.

\section{Aim of the Research and Method Used}

The basic aim of this research was to identify the specific knowledge and skills in demand by employers through a content analysis of job advertisements. As Clyde ${ }^{16}$ notes: 'Statements in job advertisements represent the knowledge and skills that employers would like to have and are prepared to pay for'. Further research will include focus group meetings with other stakeholders such as employers, graduates and other employees, professional bodies, regulators and recruitment consultants. An analysis of the findings will be measured against the relevant principles, standards and perceived educational requirements of the recordkeeping discipline and then used to evaluate courses in order to determine possible future directions for recordkeeping education.

\section{Content Analysis}

A content analysis of recordkeeping job advertisements in The West Australian, Saturday edition, for the year 2000 was conducted to identify the specific knowledge and skills in demand by employers. A wide range of position descriptions was collected from the sections of the newspaper headed Professional Appointments, Classified Section, Local Government, Education etc. All advertisements with a direct connection to recordkeeping were included. To be considered a direct connection to recordkeeping the position advertised had to include at least one recordkeeping function, aspect or responsibility. As well as the obvious records management positions, advertisements for administrative office positions, information management, knowledge management, project management, and archives etc were also carefully scrutinised for stated recordkeeping aspects. Advertisements relating to information technology, libraries, financial office administration etc were only included if they had a specific recordkeeping component. Documentation/ export/despatch clerk positions were generally not applicable as they tended to focus on batch processing of invoices rather than more traditional recordkeeping functions. Micrographics, medical records/information and preservation positions were not included, as they required specialised qualifications and experience in these areas. The Public Service Notices job vacancy advertisements in the Western Australian Government InterSector 
magazine were not included in the analysis either as these are not widely available outside the Public Service. When taking into account the information obtained from recruitment consultants and an earlier survey of graduate employment, ${ }^{17}$ it is estimated that the job advertisements represent about $50 \%$ of all placements in the industry in Western Australia at the time. In total, 79 different positions were identified in the job advertisements. A small percentage, 6.3\%, was advertised more than once. These re-advertisements were not included in the analysis.

The analysis was structured to gain a broad description of the positions advertised as well as identify the knowledge and skills in demand by employers. A data collection form was designed to ensure that consistent information was collected from all advertisements. Information from data sheets was transferred into SPSS, a statistical software program. The advertisements were scrutinised to ascertain time of year of advertisement, industry sector, the reporting line, title, description and responsibilities of position, whether full-time or part-time, whether permanent or contract, essential and desirable criteria of the position, salary level, type and length of experience required, qualifications required and whether or not eligibility for professional membership of a relevant professional body was required.

\section{Results of Analysis \\ Overview of Positions Advertised}

The advertisements were spread over all months of the year except April, with a high of $16.5 \%$ in August. The industry sector advertising the greatest number of positions available was state government with $43 \%$. This was followed by local government with $27.8 \%$, the education sector $15.2 \%$, the Commonwealth government sector and the resources industry $5.1 \%$ each, and other private sector advertisements 3.8\%. State, local and Commonwealth government positions totalled $75.9 \%$ of the advertisements. An additional two-thirds of the education advertisements were in the public sector, thus the overall public sector proportion of advertisements were $85.9 \%$.

Positions advertised were not restricted to entry-level positions. The advertisements covered a broad range of opportunities in recordkeeping for professionals and para-professionals ranging from the Director of the State Records Office, to education, advisory and consultancy roles, to coordinators or managers of freedom of information and records management, to knowledge manager, to records systems administrator, to archivist, to registry officer and mail clerk (see Table 1). The positions advertised have been grouped into a number of categories for analysis: those with management responsibility for the recordkeeping program of the organisation; those providing support to the records management program; those that have another responsibility in 
addition to recordkeeping; and those with consultancy, education/training or higher level strategic planning roles allied to recordkeeping.

Table 1

Title of Position Advertised

\begin{tabular}{|l|c|c|}
\hline & $\begin{array}{c}\text { Frequency } \\
\text { n }\end{array}$ & $\begin{array}{c}\text { Percent } \\
\mathbf{\%}\end{array}$ \\
\hline Recordkeeping responsibility & & \\
\hline Records manager/ co-ordinator & 14 & 17.8 \\
\hline Senior records officer/clerk & 8 & 10.1 \\
\hline Sub Total & 22 & 27.9 \\
\hline Recordkeeping support role & 1 & 1.3 \\
\hline Mail clerk (entry-level) & 2 & 2.5 \\
\hline Clerical officer (entry-level) & 18 & 22.8 \\
\hline Records/registry officer (entry-level) & 3 & 3.8 \\
\hline Indexing officer & 2 & 2.5 \\
\hline Records systems administrator & 4 & 5.1 \\
\hline EDMS/document manager & 2 & 2.5 \\
\hline Document control officer & 2 & 2.5 \\
\hline Archives officer/ manager & 3 & 3.8 \\
\hline Librarian (Local studies) & 37 & 46.8 \\
\hline Sub Total & & \\
\hline Recordkeeping \& additional responsibility & 2 & 2.5 \\
\hline Manager Records \& FOI & 8 & 10.1 \\
\hline Information resources co-ordinator (RM\&LIS) & 5 & 6.3 \\
\hline KM/CIO/RM & 15 & 19 \\
\hline Sub Total & & 6.3 \\
\hline $\begin{array}{l}\text { Consultancy/advisory/education/training/ } \\
\text { strategic role }\end{array}$ & 79 & $100 \%$ \\
\hline Director/Manager State Records Office & 4 & 5.1 \\
\hline $\begin{array}{l}\text { Consultancy/advisory/education/training/ } \\
\text { strategic focus }\end{array}$ & & \\
\hline Sub Total & & \\
\hline Total & & \\
\hline
\end{tabular}

In $57 \%$ of the positions advertised the reporting line was not indicated. Where it was indicated the lower level positions reported largely to the records manager and higher level positions to the corporate or administrative services manager.

The overwhelming majority, 87.3\%, of recordkeeping job vacancies advertised was full-time (69 out of 79), and almost 70\% (55) were permanent positions. Cross-tabulation of full-time, part-time, permanent and contract positions showed that $65.8 \%$ (52 of 79 ) were full-time permanent positions, 
21.5\% (17) were full-time contract, 8.9\% (7) were part-time contract, and 3.8\% (3) were part-time permanent.

As the positions advertised were not restricted to entry-level positions ${ }^{18}$ the salaries offered covered a wide range from around $\$ 20,000$ to over $\$ 70,000$. Fourteen $(17.7 \%)$ of the advertisements did not specifically mention salary, some simply stating that 'a competitive remuneration package commensurate with skills and experience' would be offered to the successful candidate. The greatest number of positions indicating salary (30 out of 65, or $46.2 \%$ ) was in the $\$ 30,000-40,000$ range.

\section{Overview of Principal Responsibilities}

When analysing the responsibilities of the various positions advertised (see Table 2), the largest group, 40.5\% (32) had wide ranging responsibilities for the recordkeeping program, although the title of the position and the salary offered may not necessarily reflect this level of responsibility (compare Table 1 and Table 2). This broad responsibility included various aspects of the program from planning and development to overall supervision of day-to-day operations. Another 22.8\% (18 advertisements) had additional responsibilities such as freedom of information, knowledge management or library services as well as records management, and a further $10.2 \%$ (8) had advisory, consultative or strategic development responsibility for records management.

The analysis by principal responsibility indicates that a fairly small percentage of the advertised positions (26.5\%) is suitable for those at the lower levels in the profession. This raises the question of how these jobs are being filled. Further investigation supports the assertion that lower level technician or para-professional placements are more likely to be filled without advertisement, for example through contracts with recruitment consultants or networking, whereas higher level professional positions are more likely to be advertised. Information Enterprises Australia ${ }^{19}$ notes that in Western Australia over $80 \%$ of on-hired staff are for records clerk and technician level positions. Previous research on the career history of Curtin University recordkeeping graduates indicates that $46.9 \%$ obtained their first position from networking contacts $^{20}$. Cox ${ }^{21}$ also notes that in a 1996-97 survey of entry-level archives positions in the United States, 202 out of 230 (87.8\%) were posted on the Internet and it is noted that it has also become commonplace to post job positions on listservs in Australia.

\section{Table 2}

\section{Principal Responsibilities of Position Advertised}




\begin{tabular}{|l|c|c|}
\hline \multicolumn{1}{|c|}{ Principal responsibilities } & $\begin{array}{c}\text { Frequency } \\
\text { n }\end{array}$ & $\begin{array}{c}\text { Percent } \\
\%\end{array}$ \\
\hline Recordkeeping management responsibility & & \\
\hline Broad range of recordkeeping practices & 32 & 40.5 \\
\hline Sub Total & 32 & 40.5 \\
\hline Recordkeeping support role & & \\
\hline Indexing \& registration & 6 & 7.6 \\
\hline Mail \& file management & 2 & 2.5 \\
\hline Systems administration (RM/LIS/database) & 6 & 7.6 \\
\hline EDM \& workflow & 3 & 3.8 \\
\hline Archiving & 2 & 2.5 \\
\hline $\begin{array}{l}\text { Administrative support/management including } \\
\text { RM }\end{array}$ & 2 & 2.5 \\
\hline Sub Total & 21 & 26.5 \\
\hline Recordkeeping \& additional responsibility & & \\
\hline Records management \& FOI & 9 & 11.4 \\
\hline Knowledge management & 2 & 2.5 \\
\hline RM \& LIS & 7 & 8.9 \\
\hline Sub Total & 18 & 22.8 \\
\hline $\begin{array}{l}\text { Consultancy/advisory/education/training/ } \\
\text { strategic role }\end{array}$ & & \\
\hline FOI administration & 1 & 1.3 \\
\hline Consultancy/advisory/education/training & 4 & 5.1 \\
\hline Strategic development information resources & 3 & 3.8 \\
\hline Sub Total & 8 & 10.2 \\
\hline Total & & 100.0 \\
\hline
\end{tabular}

\section{Essential Criteria}

Two separate aspects of essential criteria were analysed, those directly related to recordkeeping and the transferable workplace competencies such as computer literacy, interpersonal skills, broad communication skills, self and team management skills, and intellectual skills.

Surprisingly, slightly less than three-quarters (73.4\%) of the advertisements rated records management knowledge and experience as essential criteria. Those advertisements listing one or more specific aspects of recordkeeping knowledge and experience required as essential criteria varied from a knowledge of controlled language to freedom of information (FOI) and knowledge management. Over half (50.6\%) required knowledge and experience in automated systems such as TRIM, 26.6\% required a formal qualification in records management or progress towards same, $22.8 \%$ a knowledge of the relevant statutory requirements, 19\% knowledge and experience in EDM and workflow, 15.2\% required broader information or knowledge management experience, 10.1\% knowledge and experience in FOI, and $8.9 \%$ knowledge and experience in controlled language. 
Considerable emphasis is placed on transferable workplace competencies as essential criteria: overall $69.6 \%$ of the recordkeeping advertisements nominated some aspects of transferable workplace competencies as essential criteria. Over half (59.5\%) of advertisements required a high level of computer literacy, 54.4\% required well developed communication and interpersonal skills, 53.2\% well developed teaming skills, 35.4\% required a well developed customer focus, $13.9 \%$ required demonstrated management skills, $12.7 \%$ required staff supervisory skills, and $6.3 \%$ training skills and experience. Other essential criteria not specifically related to recordkeeping but mentioned in the advertisements included: enthusiasm and motivation 30.4\%, organisational and time management skills $24.1 \%$, analytical and problem solving skills $16.5 \%$, leadership skills $10.1 \%$. A range of other skills and attributes such as project management, continuous improvement, integrity and confidence were also mentioned but none more than twice.

The Department of Education, Science and Training ${ }^{22}$ labels these skills the 'generic employability competencies' and together with the Australian National Training Authority (ANTA) funded a project to identify the employability skills required by large, medium and small Australian enterprises in a wide variety of contexts. The project was conducted by the Business Council of Australia and the Australian Chamber of Commerce and Industry. It was completed in March 2002. The definition of employability skills used in the project was 'skills required not only to gain employment, but also to progress within an enterprise so as to achieve one's potential and contribute successfully to enterprise strategic directions'. The project built on and reinforced the value of the Mayer Key Competencies identified in 1992 (collecting, analysing and organising information; communicating ideas and information; planning and organising activities; working with others and in teams; using mathematical ideas and techniques; solving problems; and using technology) and added another dimension to the competencies required, that of 'personal attributes'. This was the 'term used to describe a set of non-skillbased behaviours and attitudes that employers felt were as important as the employability skills and other technical or job-specific skills, ${ }^{23}$ and not restricted to entry-level employees or positions. An Employability Skills Framework was developed to incorporate all these features. It is expected that one of the most important uses of the framework might be its use 'by those developing curricula, courses and training programs, learning aims and objectives, and learning tools for schools, VET [Vocational Education and Training sector] and higher education. The framework provides clarity with regard to what skills are required and what capacities (elements in the framework) graduates should be able to exhibit'. ${ }^{24}$ Another of the uses suggested for the framework is as a basis for the development of job descriptions. 
Table 3

Essential and Desirable Criteria of Positions Advertised

\begin{tabular}{|c|c|c|c|c|c|c|}
\hline \multirow{3}{*}{$\begin{array}{c}\text { Criterion } \\
\text { Recordkeeping competencies }\end{array}$} & \multicolumn{2}{|c|}{ Essential } & \multicolumn{2}{|c|}{ Desirable } & \multicolumn{2}{|c|}{ Total } \\
\hline & \multirow[t]{2}{*}{$\mathbf{n}$} & \multirow[t]{2}{*}{$\%$} & \multirow[t]{2}{*}{$\mathbf{n}$} & \multirow[t]{2}{*}{$\%$} & \multirow[t]{2}{*}{$\mathbf{n}$} & \multirow[t]{2}{*}{$\%$} \\
\hline & & & & & & \\
\hline Knowledge & 58 & 73.4 & 1 & 1.25 & 59 & 74.5 \\
\hline Skills & 58 & 73.4 & 1 & 1.25 & 59 & 74.5 \\
\hline None indicated & 21 & 26.6 & 77 & 97.5 & N/A & N/A \\
\hline \multicolumn{7}{|l|}{$\begin{array}{l}\text { Specific recordkeeping knowledge or } \\
\text { skill required }\end{array}$} \\
\hline Database (TRIM/db Text etc) & 40 & 50.6 & 4 & 5.1 & 44 & 55.7 \\
\hline $\begin{array}{l}\text { Formal recordkeeping (or related } \\
\text { discipline) qualification or progress } \\
\text { towards }\end{array}$ & 21 & 26.6 & 9 & 11.4 & 30 & 38 \\
\hline Knowledge of statutory compliance & 18 & 22.8 & 2 & 2.5 & 20 & 25.3 \\
\hline $\begin{array}{l}\text { Electronic data management and } \\
\text { workflow }\end{array}$ & 15 & 19 & 3 & 3.8 & 18 & 22.8 \\
\hline $\begin{array}{l}\text { Knowledge management/broader } \\
\text { information management }\end{array}$ & 12 & 15.2 & 1 & 1.3 & 13 & 16.5 \\
\hline Freedom of Information & 8 & 10.1 & 1 & 1.3 & 9 & 11.4 \\
\hline Controlled language & 7 & 8.9 & 1 & 1.3 & 8 & 10.1 \\
\hline $\begin{array}{l}\text { Others (indexing, registration, } \\
\text { archiving, retention \& disposal etc) }\end{array}$ & 13 & 16.5 & 7 & 8.9 & 20 & 25.3 \\
\hline None indicated & 20 & 25.3 & 55 & 69.6 & N/A & N/A \\
\hline \multicolumn{7}{|l|}{$\begin{array}{l}\text { Transferable employability } \\
\text { competencies }\end{array}$} \\
\hline High level of computer literacy & 47 & 59.5 & 0 & 0 & 47 & 59.5 \\
\hline $\begin{array}{l}\text { Well developed communication and } \\
\text { interpersonal skills }\end{array}$ & 43 & 54.4 & 0 & 0 & 43 & 54.4 \\
\hline Well developed teaming skills & 42 & 53.2 & 0 & 0 & 42 & 53.2 \\
\hline Well developed customer focus & 28 & 35.4 & 0 & 0 & 28 & 35.4 \\
\hline Management skills & 11 & 13.9 & 0 & 0 & 11 & 13.9 \\
\hline Staff supervision & 10 & 12.7 & 0 & 0 & 10 & 12.7 \\
\hline Training skills & 5 & 6.3 & 1 & 1.3 & 6 & 7.6 \\
\hline $\begin{array}{l}\text { Others (strategic planning, } \\
\text { continuous improvement, project } \\
\text { management, change management } \\
\text { etc) }\end{array}$ & 21 & 26.6 & 5 & 6.3 & 26 & 32.9 \\
\hline None indicated & 24 & 30.4 & 73 & 92.4 & N/A & N/A \\
\hline \multicolumn{7}{|l|}{ Personal attributes } \\
\hline $\begin{array}{l}\text { Motivation/initiative/flexibility/ } \\
\text { innovation }\end{array}$ & 24 & 30.4 & 0 & 0 & 24 & 30.4 \\
\hline $\begin{array}{l}\text { Organisational skills/time } \\
\text { management }\end{array}$ & 19 & 24.1 & 0 & 0 & 19 & 24.1 \\
\hline Analytical/problem solving & 13 & 16.5 & 0 & 0 & 13 & 16.5 \\
\hline
\end{tabular}




\begin{tabular}{|c|c|c|c|c|c|c|}
\hline Leadership & 8 & 10.1 & 0 & 0 & 8 & 10.1 \\
\hline $\begin{array}{l}\text { Others (integrity, decision-making, } \\
\text { confident, well presented etc) }\end{array}$ & 9 & 11.4 & 2 & 2.5 & 11 & 13.9 \\
\hline None indicated & 24 & 30.4 & 77 & 97.5 & N/A & N/A \\
\hline \multicolumn{7}{|l|}{ Type of experience } \\
\hline Records management & 58 & 73.4 & 1 & 1.3 & 59 & 74.7 \\
\hline $\begin{array}{l}\text { Database/record management } \\
\text { system/EDMS }\end{array}$ & 13 & 16.5 & 5 & 6.3 & 18 & 22.8 \\
\hline Records and FOI & 9 & 11.4 & 1 & 1.3 & 10 & 12.7 \\
\hline $\begin{array}{l}\text { Other ('relevant' archives, library } \\
\text { etc) }\end{array}$ & 21 & 26.6 & 2 & 2.5 & 23 & 29.1 \\
\hline None indicated & 2 & 2.5 & 70 & 88.6 & N/A & N/A \\
\hline \multicolumn{7}{|l|}{ Type of qualification } \\
\hline Recordkeeping or EDMS & 14 & 17.7 & 12 & 15.2 & 26 & 32.9 \\
\hline Related/relevant discipline & 15 & 19 & 2 & 2.5 & 17 & 21.5 \\
\hline Other (archives, library, IT etc) & 6 & 7.6 & 1 & 1.3 & 7 & 8.9 \\
\hline None indicated & 44 & 55.7 & 64 & 81 & N/A & N/A \\
\hline \multicolumn{7}{|l|}{ Level of qualification } \\
\hline Tertiary & 22 & 27.8 & 3 & 3.8 & 25 & 31.6 \\
\hline $\begin{array}{l}\text { Progress towards relevant tertiary } \\
\text { qualification }\end{array}$ & 5 & 6.3 & 0 & 0 & 5 & 6.3 \\
\hline Year 10/12 & 1 & 1.3 & 0 & 0 & 1 & 1.3 \\
\hline Not indicated & 51 & 64.6 & 79 & 79 & N/A & N/A \\
\hline \multicolumn{7}{|l|}{$\begin{array}{l}\text { Eligibility for professional } \\
\text { membership }\end{array}$} \\
\hline Records Management & 4 & 5.1 & 0 & 0 & 4 & 5.1 \\
\hline Library & 2 & 2.5 & 0 & 0 & 2 & 2.5 \\
\hline Archives & 1 & 1.3 & 0 & 0 & 1 & 1.3 \\
\hline Computer & 1 & 1.3 & 0 & 0 & 1 & 1.3 \\
\hline None indicated & 71 & 89.9 & 79 & 79 & N/A & N/A \\
\hline
\end{tabular}

\section{Desirable Criteria}

Most advertisements focussed largely on essential criteria. Almost $70 \%$ of the advertisements did not mention desirable criteria at all, whether record-related or otherwise. Those indicating desirable criteria included knowledge of automated recordkeeping systems and/or electronic document management, and a relevant tertiary qualification or progress toward one. As with essential criteria a range of other skills and experience were mentioned: knowledge of records management, database systems, electronic data management, controlled language, FOI, government administration, the resources industry, relevant experience, knowledge of existing systems, eligibility for professional membership of a relevant professional body, and technical drawing. 


\section{Experience Required}

Length and type of experience required were both analysed. Length of experience does not appear to be a major issue as only $15.2 \%$ of advertisements specifically mentioned it. The most usual requirement was 'extensive', 'relevant', 'proven', or 'suitable' experience and these descriptors could apply equally to type of experience. By comparison, type of experience was far more important with $97.5 \%$ of advertisements mentioning at least one specific skill area. Experience required varied from straight recordkeeping to library, archive and museum, information technology and EDMS, FOI, broad management, strategic planning and policy development. Many of the positions advertised required a combination of information profession skills and experience.

\section{Qualifications Required}

Level and type of qualification required were both analysed. Well over half the advertisements (51 out of 79: 64.6\%) did not mention the level of qualification required at all. One advertisement required year 10-12 completion. Thirty advertisements (38\%) stated tertiary completion or progress towards it, in recordkeeping or a relevant information management area, as either an essential or desirable criterion. When type of qualification is analysed, again quite a large percentage of advertisements do not identify type as essential (44 out of 79, 55.7\%). Forty-three advertisements (54.4\%) specifically indicating the type of qualification required as an essential or desirable criterion list recordkeeping and/or EDMS or a related discipline. The remaining qualifications required (8.9\%) relate to librarianship, archives and information technology.

Cross tabulation of type of experience required and level of qualification $(n=28)$ shows that $50 \%$ of the advertisements require qualification at the tertiary level in the recordkeeping area, followed by $14.3 \%$ in freedom of information as well as recordkeeping. And cross tabulation of salary level and level of qualification $(n=21)$ indicated that at the $\$ 30,000$ level or above $26.7 \%$ require tertiary qualifications or progress towards same.

\section{Eligibility for Professional Membership}

It is interesting to note that only eight of the 79 (10.1\%) advertisements analysed required eligibility for professional membership of a relevant professional body. Four (5.1\%) required eligibility for professional membership of the RMAA (Records Management Association of Australasia), two (2.5\%) required eligibility for membership of ALIA (Australian Library and Information Association), one (1.3\%) professional membership of the ASA (Australian Society of Archivists), and one (1.3\%) of the ACS (Australian Computer Society). 


\section{Discussion of Employer Requirements}

From an analysis of the positions advertised it is clear that employers expect recordkeeping professionals to possess a diverse range of recordkeeping knowledge and experience, ranging from basic entry-level domain specific hands-on processing skills to higher level strategic planning skills relevant to the level of the position. Often positions require knowledge and experience in more than one area of information management, for example, recordkeeping and library studies or recordkeeping and freedom of information. It is disturbing, however, to note that $26.6 \%$ of the positions advertised did not list knowledge and experience of recordkeeping as essential criteria. It is possible that some employers do not see that see these skills as essential and can be learnt on the job. One suspects that some of this may be due to sloppy advertisement preparation as when cross tabulating the criteria of recordkeeping knowledge and experience against the title of the position, one discovers that four positions (of eight) for the coordinator of information services (recordkeeping and an additional information related area), and one advertisement for a consultancy advisory position, did not ask for recordkeeping knowledge and experience. However, generally the positions omitting these criteria were low to mid-level positions such as records officer, mail clerk, and document control officer and employers may well consider other workplace competencies and personal attributes more important.

The preferred recordkeeping professional will also be proficient in transferable employment competencies or skills such as a high level of computer literacy, well developed communication and interpersonal or people skills, staff management skills and experience, well developed teaming skills, and a strong customer focus. Recruitment consultants such as Information Enterprises Australia (IEA) also note that similar skills are in great demand by employers, and add to the list professional image and manner and the ability to handle sensitive material with strict confidentiality. ${ }^{25}$ In a small number of advertisements these skills were listed as 'essential' whereas recordkeeping skills were not. Personal attributes such as enthusiasm, motivation, and analytical and problem solving skills were also considered of prime importance.

Over one-third (38\%) of the advertisements indicated that a tertiary qualification or progress towards a tertiary qualification was either an essential or a desirable criterion. Type of qualification required varied from recordkeeping to archives, library, information technology or a related discipline. This is in stark contrast to the United States and Canada where the research shows that a considerably higher proportion of records managers have tertiary qualifications. Cunningham's ${ }^{26}$ salary survey showed that $68.2 \%$ of records and information managers had at least a four-year degree and this was considered the minimum educational requirement, with the best jobs requiring 
a masters degree. Cunningham also noted that 'with the current paradigm shift in the information environment those with the older MLS (Master of Library Science) degree are being passed up for those with the newer MIS (Master of Information Science) degree' and that the possession of a CRM is vital to career progression. Certified Records Managers (CRMs) are professional records and information managers from a growing number of countries including the United States, Canada, New Zealand, Australia and Japan. Each individual is experienced in active and inactive records systems and related disciplines such as archives, computerisation, micrographics and optical disk technology. CRMs receive the CRM designation by meeting both educational and work experience certification requirements established by the Institute of Certified Records Managers (ICRM) and by passing the required examinations. The ICRM is an international certifying organisation of and for professional records and information managers. It was incorporated in 1975 to meet the requirement to have a standard by which persons involved in records and information management could be measured, accredited and recognised according to criteria of experience and capability established by their peers. ${ }^{27}$

In his Handbook for Records Management Careers, Cunningham ${ }^{28}$ identifies 'Three Pillars' for a successful career in records management: education, experience and professional development. He notes that it is easier to obtain experience in records management than many other professions but that as positions become better paid they became more competitive and professionals will need to demonstrate certification, higher levels of achievement in all areas and be visible and active in the profession. Observation suggests that this is also the case in Western Australia. In the case of the Curtin University undergraduate degree in records management, 59\% of students entered the degree with prior experience in records management and were completing the degree to enhance their career prospects. It has indeed enhanced their prospects as is evidenced by their subsequent career progression since graduation. ${ }^{29}$

A disappointingly small percentage, 5.1\% (4 out of 79), of the positions advertised required eligibility for professional membership of the RMAA. When one surveys professional library advertisements per se the picture is quite different as the vast majority of such advertisements do mention eligibility for professional membership of ALIA as an essential criterion. A mini-analysis of professional library positions in The West Australian for a representative month (August 2000) within the same period of the recordkeeping analysis located 11 advertisements. All of these mentioned eligibility for professional membership of ALIA as an essential criterion. What implication does this comparison have for the level of professionalism in recordkeeping? How can we expect others outside the profession to take us seriously as professionals when we don't take it seriously ourselves? 


\section{Conclusion}

The recordkeeping environment is in a state of flux. The need to focus on constantly evolving technology, changing functions, regulatory requirements, and standards etc increases the pressure on professionals in the field. Research indicates a serious lack of qualified professionals in the area. How best to address this issue is one of concern for the industry as a whole. Initiatives such as the Better Skills Program (State Records NSW) and the ARES Forum show that professionals are vitally concerned.

Content analysis of advertised recordkeeping positions does provide a useful guide to the requirements of those employing recordkeeping professionals. One could make statements about the relationship of these identified requirements to current best practice recordkeeping and the level of professionalism in the discipline, however, it is premature at this stage of the research.

How best to acquire the required knowledge and skills is another issue. As well as the traditional TAFE and university approaches to education it may be appropriate to investigate other options. The research of Gonczi ${ }^{30}$ into vocational and higher education and competency based training, indicates that the perennial problem of the 'theory-practice gap' may be alleviated by closer ties between universities, vocational colleges and professional practice (the employers). He sees apprenticeship models for undergraduate education at one end of the continuum and postgraduate work-based learning degrees at the other. Degrees based on this model include an active partnership between professionals in the workplace, the student and the university. Is this a model that can be applied to recordkeeping education in Australia? Given that so many recordkeepers have learnt their skills through on-the-job training or have come from another information discipline rather than a traditional university education the option deserves further investigation. The greatest challenges to this proposed learning paradigm might well be the assumptions of tertiary educationalists and resistance from the profession itself.

It is expected that focus group meetings later in the year with employers, graduates, employees, professional bodies, regulators and recruitment consultants will provide additional qualitative data about the knowledge and skills required for recordkeeping positions, as will other research such as that conducted by The One Umbrella Group. ${ }^{31}$ These data will also indicate whether there have been any changes in demand since 2000. Findings will need to be rigorously evaluated against the myriad of standards and principles relevant to recordkeeping. ${ }^{32}$ Outcomes can then be mapped against current courses and the results used for further course structure and content development. 


\section{Notes}

1 The Auditor-General's report to Parliament for 2002, vols 5 \& 6 www.audit.nsw.gov. au/agrep02v5/Contents.htm \& www.audit.nsw.gov.au/agrep0206/Contents/htm [March 2003]

2 State Records NSW Standard on Records Management Programs no 21998 State Records NSW 'Standard on Recordkeeping in the Electronic Business Environment no 4 Sydney AANSW 2000

3 J Evans 'Records Profession Skills Weakness Exposed by NSW Records Compliance Audit' Informaa Quarterly vol 19 no 1 February 2003 pp 8-11

4 State Records NSW Standard on Records Management Programs no 2 Sydney AANSW 2000

5 G Murphy 'Where Have All the Records Practitioners Gone: A View From the West Coast' ARES Forum, Melbourne 12-13 June 2003 http://www.archivists.org.au/events/ ARES2003/index.html

6 J Evans 'Serious Lack of Skilled and Qualified Records Professionals in NSW' Informaa Quarterly vol 18 no 42002 pp 16-20

7 Evans 'Records Profession ...' p8

8 State Records Office NSW Building Better Records Management Skills: Guideline no 17 Sydney SRNSW May 2003 http://www.records.nsw.gov.au/publicsector/rk/ guidelines/better_skills/Title.htm

9 R K Cunningham Handbook for Records Management Careers http://www.staff. uiuc.edu/ rcunning/job.htm 1997 [21 May 2003] Updated 8 September 2000

10 R K Cunningham 1998 Salary Survey Results for the United States and Canada http://www.staff.uiuc.edu/ rcunning/job.htm [21 May 2003]

11 Australian National Training Authority Glossary of VET terms http://www.anta.gov.au/glo.asp

12 R J Cox 'Employing Records Professionals in the Information Age' Information Management Journal vol 34 no 12000 pp18-33

13 B M Webster 'Records Management: From Profession to Scholarly Discipline' Information Management Journal vol 33 no 41999 pp 20, 22, 24-30

14 D H Liles M E Johnson L Meade and D R Underwood 'Enterprise Engineering: A Discipline?' Society for Enterprise Engineering Conference Proceedings June 1995

15 D H Liles M E Johnson and L Meade 'The Enterprise Engineering Discipline' Paper presented at 5th Industrial Engineering Research Conference Minneapolis MN 1996 Proceedings published 1997 pp479-484 accessed 18 April 2003 http://arri.uta.edu/eif/ent_eng.htm at p481

16 L A Clyde 'An Instructional Role for Librarians: An Overview and Content Analysis of Job Advertisements' Australian Academic \& Research Libraries vol 33 no 3 September 2002 pp150-166 at p155

17 M Pember 'A Decade of Recordkeeping Education at Curtin University of Technology: Flux and Flexibility’ Australian Library Journal vol 53 no 12003 pp6579

18 R J Cox 'Employing Records Professionals ...' pp18-33

19 G Murphy 'Where Have All the Records Practitioners Gone ...' p2

20 Pember 'A Decade' ... p65

21 R J Cox ‘Employing Records Professionals ...' p23 
22 Department of Education Science and Training Employability Skills for the Future Canberra DEST 2002

23 Ibid, pp5-6

24 Ibid, p37

25 G Murphy 'Where Have All the Records Practitioners Gone ...' p4

26 R K Cunningham Handbook for Records Management Careers

27 http://www.icrm.org/intro.html

28 Cunningham Handbook for Records Management Careers p3

29 M Pember 'Do You Really Need a Degree? Preliminary Report into a Decade of Recordkeeping Education at Curtin University' Proceedings Convergence ASA \& RMAA Annual Conference Hobart ASA \& RMAA 2001 pp229-241

30 A Gonczi 'Advances in Educational Thinking and Their Implications for Professional Education’ Australian Council of Professions National Conference 2001 Professional Education for a Changing World. Electronic copy from author June 2003

31 One Umbrella P/L Australian Records Management Work \& Salary Surveys 2001 and 2002 http://www.oneumbrella.com.au/reports/salarysurvey/records/rmsurvey_2002. html

32 A Picot 'The Story of the Australian Recordkeeping Competency Standards’ The Records Management Journal vol 11 no 32001 pp16-24

John Levett - who is also on the Editorial Board of AARL - has similarly been reappointed as Editor of The Australian Library Journal. 